\title{
Effect of Characteristics of Health Worker in Sub Distric Public Health Centre and Endicimity Status to Preparedness in Facing Outbreak of Dengue Hemorrhagic Fever in Banda Aceh City
}

\author{
Syarifah Srimulasiyah ${ }^{1,2}$, Syahrul $^{3}$, and Indra ${ }^{4}$ \\ ${ }^{1}$ Department of Disaster Management, Graduate Program, Universitas Syiah Kuala, Banda \\ Aceh, Indonesia \\ ${ }^{2}$ Darussalam Sub District Public Health Centre, Banda Aceh Health Office, Banda Aceh, \\ Indonesia \\ ${ }^{3}$ Department of Medicine, Faculty of Medicine, Universitas Syiah Kuala, Banda Aceh, \\ Indonesia \\ ${ }^{4}$ Department of Agriculture Socio-Economic, Faculty of Agriculture, Universitas Syiah Kuala, \\ Banda Aceh, Indonesia
}

\{nassyari7806@yahoo.com,syahrulSpS@unsyiah.ac.id,indrazainun@unsyiah.ac.id\}

\begin{abstract}
The increase in incidence and affected region of dengue hemorrhagic fever (DHF) in Banda Aceh poses a high risk for health disaster or outbreak. Incidence of DHF in Banda Aceh tends to increase every year. Free-flick number in 11 sub-districts within Banda Aceh city are yet $69.1 \%$, far lower than the national standard. Thus, the preparedness of health workers in sub-district public health center dealing with health disaster due to DHF must be improved. This study aims to analyze the effect of the characteristics of health workers working in the sub-district public health center and endemicity status to preparedness in the face of DHF outbreaks in Banda Aceh City. The research design used was an analytical survey with a sample of all health workers in 11 (eleven) health centers in the city of Banda Aceh, totaling 165 people. Data collection was done using a questionnaire and analyzed by univariate, bivariate and multivariate. The results showed that gender, length of service and training partially related to preparedness of health workers in dealing with DHF outbreaks. It was found that gender, job title, duration of duty and training is partially related to the preparedness of health workers in dealing with DHF outbreaks. The analysis results from binary logistic regression show that age, duration of duty and training are significant predictors of the preparedness of health staff in the Public Health Centre in dealing with DHF outbreaks. The result also shows that the older the health worker age, the more prepared in dealing with DHF outbreak. Similarly, the longer duration of duty the better prepared the health workers on the face of DHF outbreak. It was also found that training is the most dominant predictor affecting the preparedness of health workers in dealing with DHF outbreak. Based on these results, it is suggested to Banda Aceh Health Office to facilitate and advocate training activities related to DHF countermeasure by providing the necessary budget. It is also suggested that the transfer of medical workers should consider and maintain employee with long duration of duty due to their experiences in facing the DHF outbreak.
\end{abstract}

Keywords: Characteristics of health workers, endemicity, preparedness, health workers, DHF outbreaks 


\section{Introduction}

World Health Organization (WHO) has classified disaster into 3 categories, namely (1) natural disaster, (2) non natural disaster, and (3) social disaster. A non natural disaster is a disaster caused by an event or a series of events of non-natural origins such as the event of a health disaster in the form of a disease outbreak [1]. One disease that has the high potential to become a health disaster is Dengue Hemorrhagic Fever (DHF). DHF is an endemic disease caused by arboviral with significantly increased morbidity and mortality in tropical and subtropical regions all over the world [2].

DHP incidence increases 30 folds and expands geographically into new countries including urban and rural areas. Nowadays, there are approximately 2.5 billion people or more than $40 \%$ of the world population poses a high risk for DHF. WHO reported that there are 50 to 100 millions DHF incidences in the whole world every year. DHF disease initially an epidemic occurred in nine countries in 1970. However, nowadays DHF is become epidemic in more than 100 countries spreading from Africa, America, East Mediterranean, South East Asia to West Pacific. America, South East Asia, and West Pacific regions are the most seriously affected regions. DHF cases all over America, South East Asia, and West Pacific regions has exceeded 1.2 million cases in 2008 and over 2.3 million cases in 2010. A recent report shows that the number of DHF case is continuously increasing. It was reported just in America, there are 1.6 million dengue fever cases occurred and 49.000 cases are severe DHF in 2010 [2].

It was reported that there 100.347 DHF cases with death toll of 907 persons (Incidence Rate $(\mathrm{IR}) /$ morbidity $=39,8$ per 100.000 population and Case Fatality Rate $(\mathrm{CFR}) /$ mortidity $=0,9 \%)$ in Indonesia on 2014 (Kemenkes, 2015) and it increases to 129.650 cases with death toll of 1.071 persons $(\mathrm{IR} /$ morbidity $=50,75$ per 100.000 population and $\mathrm{CFR} /$ mortidity $=0,83 \%$ ) on 2015. Even it increased significantly in 2016 reaching 204.171 cases with a death toll of 1.598 persons. IR also increases as compared to 2015 , namely from 50,75 per 100.000 population to 78,85 per 100.000 population. However, CFR due to DHF decreases from $0,83 \%$ to $0,78 \%$ (Kemenkes, 2017). The target of the strategic plan of the Indonesian Health Ministry for the morbidity of DHF in 2015 is < 49 per 100.000 population, meaning Indonesia has yet reached the target of the 2015 strategic plan.

Data from Aceh Public Health Office shows DHF incidence in Aceh in 2014 was 2.211 cases and death toll was 7 persons (IR/mobility $=45$ per 100.000 population). The number of DHF incidence in 2015 was 1.510 cases with a dead tool of 6 persons (IR/morbidity $=30$ per 100.000 population and $\mathrm{CFR} /$ mortality $=0,4 \%$ ), showing a decrement as compared 2014 [3] However, it reached 2.643 cases on 2016, boldly increases, about $70 \%$ from 2015 . The death toll also increases largely, from 6 persons in 2015 to 19 persons in 2016.

While in Banda Aceh city, there are 299 DHF cases in 2014, however, there was no death (Dinkes Kota Banda Aceh, 2015). There are only 127 DHF cases in Banda Aceh in 2015, significantly decrease as compared to 2014. There was one person died in 2015 [3]. DHF incidence in Banda Aceh city again increases in 2016, reaching 152 cases as compared to 2015. But there was no death. Similarly, it again increases significantly in 2017, reaching 236 cases. Furthermore, the average value of flick free, called larva free numbers (Angka Bebas Jentik, ABJ in Indonesian) on 2017 in 11 sub-districts within the city of Banda Aceh was only 69.1\%, still far away from the national standard, namely $\geq 95 \%$. This means that on average in subdistricts in the city of Banda Aceh there are still many larvae of dengue mosquitoes [3].

The increase in cases and the extent of the spread of DHF in the city of Banda Aceh has the potential to be a non-natural disaster, namely health disaster (outbreaks). Regulation from 
Minister of Health of the Republic of Indonesia Number 82 on 2014 concerning Prevention of Communicable Diseases states that outbreaks are the occurrence or increase in the incidence of morbidity and/or death that is epidemiologically meaningful in an area over a period of time, and is a condition that can lead to outbreaks [5].

Based on the principle of disaster risk assessment proposed by the United Nations International Strategy for Disaster Reduction [6], namely the existence of hazards in the form of the growth of dengue mosquito larvae that are evenly distributed in each sub-district indicated by an average value of free flick number is still low $(69.1 \%<95 \%)$, there is very high potential for outbreaks. Furthermore, there is also the vulnerability of the community to be affected by DHF which is indicated by an increase in the number of DHF cases in Banda Aceh every year. Thus, Banda Aceh city poses a very high risk to outbreaks or extraordinary events (called kejadian luar biasa, KLB in Indonesian) if no serious handling measures are carried out [7].

The risk of non-natural disasters in the form of health disasters that may occur due to DHF disease in Banda Aceh City can actually be reduced. One way is to increase the preparedness of health workers in the sub-district public health center, Puskesmas, to deal with the possibility of DHF outbreaks. The Health Office of Banda Aceh City through each sub-district public health center has made efforts to reduce the risk of health disaster due to DHF outbreak, such as mobilizing the potential of the community to participate in activities for eradication of mosquito nests, called pemberantasan sarang nyamuk, PSN in Indonesian, including 3M plus, namely close (menutup), drain (menguras) and bury (mengubur). with 3M Plus. However, the number of DHF cases in Banda Aceh City is still high [8].

Several studies have proven the importance of health workers' preparedness for facing disasters. Ogedegbe, Nyirenda, DelMoro, Yamin, \& Feldman [9] showed that most of the 5,790 health workers surveyed, namely $79 \%$ strongly agreed that they knew what to do in the event of a disaster and the majority were willing to work in the event of a disaster. Clinical health workers are significantly better prepared than non-clinical health workers to deal with disasters. Older health workers are better prepared compared to young age.

Desai, Doke, \& Mohanty [10] showed a positive attitude towards the disaster planning process from the health workers and the majority of health workers had preparedness for future emergency situations. Health workers need training related to disaster preparedness. Furthermore, [11] found that $51.4 \%$ of health workers in the sub-district public health center (Puskesmas) have good disaster preparedness. Variables that relate to the preparedness of health workers for disasters are knowledge, attitudes and fixed procedures.

Considering the data and phenomena described above, the government of Banda Aceh City needs to improve the preparedness of the sub-district public health center, Puskesmas, to the risk of health disasters due to the outbreak of DHF. The preparedness of the sub-district public health center, Puskesmas, is reflected in the preparedness of health workers at the health center. Thus, the purpose of this study is to analyze the effect of the characteristics of health workers in the sub-district public health center, Puskesmas, and endemicity status to preparedness in the face of DHF outbreaks in Banda Aceh City.

\section{Research Methodology}

This research is analytic survey research. Samples were selected by purposive sampling method, namely health workers in charge of DHF prevention (doctors, nurses, sanitarians, surveillance, laboratory staff, and health promotion officers) in the sub-district public health center, Puskesmas, within the Banda Aceh City area of 165 people. Instruments for collecting data in the form of questionnaires that measure the characteristics of health workers (age, sex, education, position, length of service and training), endemicity status and preparedness of health 
workers for DHF outbreaks. The results of data collection were analyzed by univariate, bivariate and multivariate.

\section{Research Result}

\subsection{Characteristics of Health Workers}

Characteristics of health workers in the sub-district public health center, PUSKESMAS, studied in this research are age, sex, education background, length of service and training.

Table 1. Characteristics of Health Workers

\begin{tabular}{|c|c|c|c|}
\hline No & Characteristics & Frequency (f) & Percentage (\%) \\
\hline \multirow[t]{3}{*}{1} & Age & & \\
\hline & a. $\quad$ Old & 80 & 48,3 \\
\hline & b. Young & 85 & 51,7 \\
\hline \multirow[t]{3}{*}{2} & Sex & & \\
\hline & $\begin{array}{ll}\text { a. } & \text { Male }\end{array}$ & 12 & 7,3 \\
\hline & b. Female & 153 & 92,7 \\
\hline \multirow[t]{3}{*}{3} & Education & & \\
\hline & a. Graduate & 32 & 19,7 \\
\hline & b. Diploma & 133 & 80,3 \\
\hline \multirow[t]{3}{*}{4} & Length of Duty & & \\
\hline & a. $\quad$ Old & 85 & 51,7 \\
\hline & b. $\quad$ New & 80 & 48,3 \\
\hline \multirow[t]{3}{*}{5} & Training & & \\
\hline & a. $\quad$ Yes & 78 & 47,0 \\
\hline & b. No & 87 & 53,0 \\
\hline
\end{tabular}

Table 1 shows that the characteristics of health workers in the sub-district public health center, PUSKESMAS, within the Banda Aceh City, namely 85 people (51.7\%) are young, 153 people $(92.7 \%)$ women, 133 people $(80.3 \%)$ with Diploma level education, 85 people $(51.7 \%)$ have been serving in the sub-district public health center, PUSKESMAS, for a long time and 87 people $(53.0 \%)$ have never received training in disaster and emergency.

\subsection{Endemicity Status}

The measurement of endemicity status in the area in the city of Banda Aceh was based on the criteria for the number of cases and deaths from DHF for 3 consecutive years. The results of the analysis of the endemicity status of DHF in the city of Banda Aceh can be seen in Table 2.

Table 2. DHF Endemicity Status

\begin{tabular}{cccc} 
No & Endemicity & Frequency (f) & Percentage (\%) \\
\hline 1 & Endemic & 151 & 91,7 \\
\hline 2 & Sporadic & 14 & 8,3 \\
\hline & Total & 165 & 100,0
\end{tabular}

Table 2 shows that according to health workers most people or 151 people $(91.7 \%)$ stated that the city of Banda Aceh is an endemic area of DHF. 


\subsection{Preparedness of Health Workers}

The measurement of preparedness of health workers at the sub-district public health center, Puskesmas, in dealing with DHF outbreaks in Banda Aceh City uses an instrument adopted from LIPI-UNESCO/ISDR (2006)[12], which includes knowledge and attitudes, policies and guidelines, emergency response plans, early warning systems, and resource mobilization. The results of the analysis of the preparedness of health workers in dealing with DHF outbreaks are as follows:

Table 3. Preparedness of Health Workers

\begin{tabular}{llrrrr}
\multirow{2}{*}{ Preparedness } & \multicolumn{2}{c}{ Siap } & \multicolumn{2}{c}{ Tidak Siap } \\
\cline { 2 - 6 } & $\mathrm{f}$ & \multicolumn{1}{c}{$\%$} & $\mathrm{f}$ & \multicolumn{1}{c}{$\%$} \\
\hline 1. & Knowledge & 67 & 40,7 & 98 & 59,3 \\
\hline 2. & Preparedness Plan & 69 & 42,0 & 96 & 58,0 \\
\hline 3. & Warning System & 60 & 36,3 & 105 & 63,7 \\
\hline 4. & Resource Mobility & 79 & 48,0 & 86 & 52,0 \\
\hline 5. & Policy & 69 & 41,7 & 96 & 58,3 \\
\hline 6. & Preparedness & 76 & 46,3 & 89 & 53,7
\end{tabular}

Table 3 shows that most people or 98 people $(59.3 \%)$ health workers in the sub-district public health center, Puskesmas, were not prepared in terms of knowledge about DHF outbreaks. Furthermore, it was also known that 96 people (58.0\%) health workers were not ready in the emergency preparedness plan of the DHF outbreak. A total of 105 people $(63.7 \%)$ health workers were not prepared in the event of an emergency warning system for DHF outbreaks. The mobility aspect of health personnel is also not ready, as many as 86 people $(52.0 \%)$ and as many as 96 people $(58.3 \%)$ health workers are not prepared in terms of the DHF outbreak preparedness policy. In general, the preparedness of health workers in the sub-district public health center, Puskesmas, in Banda Aceh City is in the category of unprepared, which is as many as 89 people $(53.7 \%)$.

\subsection{Bivariate Analysis}

Analysis to determine the relationship between health worker characteristics and endemicity status with the preparedness of health workers in dealing with DHF outbreaks was conducted using a chi-square test. The results of the analysis can be seen in Table 4 . Table 4 shows that out of 80 health workers who are old, most of them, namely 46 people (57.5\%) are not ready to face DHF outbreaks. Furthermore, from 85 health workers who were young, the majority or 43 people $(50.6 \%)$ were also not ready to face the DHF outbreak. The results of the analysis show that $\mathrm{P}=0.356>0.05$ so that Ho is accepted which means that there is no relationship between age and health workers' preparedness in dealing with DHF outbreaks in Banda Aceh City. Furthermore, it was also known that out of 12 health workers with male sex, the majority or 9 people $(72.7 \%)$ were ready to face the DHF outbreak. Furthermore, out of 153 health workers with female sex, most of the 86 people $(56.0 \%)$ were not ready to face the DHF outbreak. The results of the analysis show that $\mathrm{P}=0.013<0.05$ so that Ho is rejected, which means there is a relationship between gender and preparedness of health workers in dealing with dengue outbreaks in Banda Aceh City. 
Table 4. Results from Bivariate Analysis

\begin{tabular}{|c|c|c|c|c|c|c|c|c|}
\hline \multirow{3}{*}{ Variable } & \multicolumn{4}{|c|}{ Preparedness } & \multirow{2}{*}{\multicolumn{2}{|c|}{ Total }} & \multirow{3}{*}{ A } & \multirow{3}{*}{ P Value } \\
\hline & \multicolumn{2}{|c|}{ Ready } & \multicolumn{2}{|c|}{ Not Ready } & & & & \\
\hline & $\mathrm{F}$ & $\%$ & $f$ & $\%$ & $f$ & $\%$ & & \\
\hline \multicolumn{9}{|l|}{ Age } \\
\hline 1. Old & 34 & 42,5 & 46 & 57,5 & 80 & 100 & \multirow{2}{*}{0,05} & \multirow{2}{*}{0,356} \\
\hline 2. Young & 42 & 49,4 & 43 & 50,6 & 85 & 100 & & \\
\hline \multicolumn{9}{|l|}{ Sex } \\
\hline 1. Male & 9 & 72,7 & 3 & 27,3 & 12 & 100 & \multirow{2}{*}{0,05} & \multirow{2}{*}{0,013} \\
\hline 2. Female & 67 & 44,0 & 86 & 56,0 & 153 & 100 & & \\
\hline \multicolumn{9}{|l|}{ Education } \\
\hline 1. Graduate & 18 & 55,0 & 14 & 45,0 & 32 & 100 & \multirow{2}{*}{0,05} & \multirow{2}{*}{0,148} \\
\hline 2. Diploma & 58 & 43,9 & 75 & 56,1 & 133 & 100 & & \\
\hline \multicolumn{9}{|l|}{ Length of Duty } \\
\hline 1. Long & 48 & 56,7 & 37 & 43,3 & 85 & 100 & \multirow{2}{*}{0,05} & \multirow{2}{*}{0,0001} \\
\hline 2. New & 28 & 34,8 & 52 & 65,2 & 80 & 100 & & \\
\hline \multicolumn{9}{|l|}{ Training } \\
\hline 1. Yes & 41 & 52,2 & 37 & 47,8 & 78 & 100 & \multirow{2}{*}{0,05} & \multirow{2}{*}{0,028} \\
\hline 2. No & 35 & 40,6 & 52 & 59,4 & 87 & 100 & & \\
\hline \multicolumn{9}{|l|}{ Endemicity Status } \\
\hline 1. Endemc & 69 & 45,8 & 82 & 54,2 & 151 & 100 & \multirow{2}{*}{0,05} & \multirow{2}{*}{0,838} \\
\hline 2. Sporadic & 7 & 50,0 & 7 & 50,0 & 14 & 100 & & \\
\hline
\end{tabular}

Table 4 also shows that out of 32 health workers with undergraduate education, the majority or 18 people $(55.0 \%)$ were ready to face the DHF outbreak. Furthermore, from 133 health workers with Diploma level education, the majority or 75 people $(56.1 \%)$ were not ready to face DHF outbreaks. Next, the results of the analysis show that $\mathrm{P}=0.148>0.05$ so that $\mathrm{H}_{\mathrm{o}}$ is accepted which means there is no relationship between education and preparedness of health workers in dealing with DHF outbreaks in Banda Aceh City. The length of service for health workers based on the table above shows that out of 85 health workers who have been on duty for a long time, most of them (48.7\%) have the readiness to face DHF outbreaks. Furthermore, the 80 new health workers on duty, most or 52 people $(59.4 \%)$ were not ready to face the DHF outbreak. The results of the analysis showed the value of $\mathrm{P}=0,0001<0,05$ so that $\mathrm{H}_{0}$ was rejected which means there is a relationship between the length of service and the preparedness of health workers to the face of DHF outbreaks in Banda Aceh City.

Furthermore, it was found that out of 78 health workers who received training, the majority or 41 people (52.2\%) were ready to face the DHF outbreak. Then from 87 health workers who did not get training, most or 52 people $(59.4 \%)$ were not ready to face the DHF outbreak. The results of the analysis show that $\mathrm{P}=0.028<0.05$ so that Ho is rejected which means that there is a relationship between training and preparedness of health workers in dealing with DHF outbreaks in Banda Aceh City. Endemicity status also showed that of 151 health workers who stated the status of their working area was DHF endemic areas, most or 82 people (54.2\%) were not ready to face DHF outbreaks. Furthermore, from 14 health workers who stated that the status of their working area was sporadic in DHF, the majority or 7 people $(50.0 \%)$ were also not ready to face the DHF outbreak. The results of the analysis show that $\mathrm{P}=0.838>0.05$ so that $\mathrm{H}_{\mathrm{o}}$ is accepted which means there is no relationship between endemicity status and preparedness of health workers in dealing with DHF outbreaks in Banda Aceh City. 


\subsection{Multivariate Analysis}

Multivariate analysis using the Binary Logistic Regression test using the Stepwise method. The repeated analysis was carried out by issuing insignificant variables from the model. The results of the analysis of the last model from the Binary Logistic Regression test using the Stepwise method can be seen in the table below.

Tabel 5. Summary of Binary Logistic Regression Analysis

\begin{tabular}{lccccc}
\multirow{2}{*}{ Predictor } & \multirow{2}{*}{$\mathrm{B}$} & \multirow{2}{*}{ OR } & P & \multicolumn{2}{c}{$95 \%$ CI } \\
\cline { 5 - 7 } & & & Value & Lower & Upper \\
\hline Age & 1,333 & 3,792 & 0,002 & 1,656 & 8,681 \\
\hline Length of Duty & 1,215 & 0,297 & 0,007 & 0,123 & 0,715 \\
\hline Training & 1,795 & 6,021 & 0,0001 & 3,335 & 10,870
\end{tabular}

Table 5 shows the results of the analysis of the Binary Logistic Regression test using the Stepwise method for the last model. These results indicate that the age variable $(\mathrm{P}$-value $=0.002)$, position $(\mathrm{P}$ value $=0,0001)$, duration of service $(\mathrm{P}$-value $=0.007)$ and training $(\mathrm{P}$-value $=0,0001)$ are significant predictors of preparedness of health workers in the face of the DHF outbreak. It was found that the older the age of health workers, the better prepared to deal with DHF outbreaks. The longer the health staff is on duty, the more prepared they will be in facing DHF outbreaks and the more often the health workers attend training, the more prepared they will be in dealing with DHF outbreaks. The results of the Binary Logistic Regression with the Stepwise method also showed that training was the most dominant predictor affecting the preparedness of health workers in dealing with DHF outbreaks (OR: 6.021) after being controlled by age (OR: 3.792) and length of time (OR: 0.297). Training affects preparedness as much as 6.021 or 6 times, age affects preparedness as much as 3.792 or 4 times and the duration of duty affects preparedness 0.297 or 0.3 times.

\section{Discussion}

The results showed that there was no relationship between age and health personnel preparedness in dealing with dengue outbreaks in Banda Aceh City $(\mathrm{P}=0.356)$. These results are in line with what was reported by Wahidah (2016), there is no relationship between age and disaster preparedness. Cornell, Cusack, \& Arbon [14] said that older people are considered to lack of preparedness for disaster events. This is related to a decrease in physical function that will affect dexterity and speed and the thought process when a disaster occurs. In contrary, Najafi, Ardalan, Akbarisari, Noorbala, \& Jabbari [15] said older people have more experience in dealing with previous disasters. Experience significantly influences disaster preparedness behavior on someone.

Robbins \& Coulter [16] said that age will affect one's physical, mental, workability, and responsibility. Drucker [17] said that older people are not as effective as young people in carrying out certain tasks. As with disaster preparedness, younger people are usually better prepared than older people. This is mainly because the body of older people is not as strong as the young to perform certain tasks efficiently. But Bolden [18] said there are some important differences between older people and those who are psychologically younger. On certain tasks, older people can do better than younger ones because of experience. Preparedness for disasters is also closely related to the experience of facing previous disasters. Older people are usually better prepared to face disasters because they have enough experience. 
Based on the above description, it is known that the results of this study differ from several theories and other studies. Many factors basically cause differences in these results. Preparedness of health workers in dealing with DHF outbreaks is a form of performance of health workers at the sub-district public health center, Puskesmas. The performance of a health worker is actually influenced by many other factors. Sharma, Webster, \& Bhattacharyya [19] stated that the motivation and performance of health workers in the community is influenced by various factors that arise from the complex context in which he/she works. This includes various personal factors (such as age), professional factors (training, job security) and organizational factors (infrastructure) along with other factors that arise from the external work environment. Referring to several differences of opinion, namely younger people have preparedness for disasters due to physical and performance factors but older people also have disaster preparedness because of experience, researchers assume that age is not a variable that significantly related to the preparedness of health workers in the sub-district public health center, Puskesmas in dealing with DHF outbreaks in the city of Banda Aceh. There are other factors that significantly relate to the preparedness of these health workers.

The results of this study also indicate that there is a relationship between gender and preparedness of health workers in dealing with DHF outbreaks in the city of Banda Aceh $(\mathrm{P}=$ 0.013). Regarding disaster preparedness issues and their relationship to gender, Mehta [20] stated that men are better able to respond in crisis or disaster situations compared to women. It is said that there is an assumption that men are physically and emotionally stronger in disaster preparedness as compared to women. Cvetković, Roder, Öcal, Tarolli, \& Dragićević [21] also said that men appear to be more confident in their abilities in disaster preparedness. However, women show a deeper understanding of disaster preparedness. Perhaps because of a deeper level of understanding, women show attitudes and behaviors that are more concerned with disaster preparedness. Furthermore [21] said that the low level of disaster preparedness was related to lower capacity and willingness to protect. Men have a higher tendency to take precautionary measures and higher knowledge about disaster preparedness. Conversely, women are caused because their main focus on child care and household responsibilities rather than work cause women to be less prepared for disaster.

Women carry out many activities related to emergency preparedness. It is also noted that women are excluded from emergency planning and preparedness decisions in developing countries. Basically, women and men carry out different preparedness activities and women are mostly not presented in formal emergency preparedness [22]. Research conducted by Ogedegbe [9] gave results that $77 \%$ of health workers studied were women. Seventy-nine percent of health workers know what to do in the event of a disaster, and the majority are willing to respond in the event of a disaster. The most common obstacle for women health workers in responding to disasters is because they have to care for children. Based on the above description, it is known that men and women have differences in preparedness in the face of disasters. Therefore researchers assume that the sex of health workers influences preparedness in the face to DHF outbreaks.

The results of the next study showed that there was no relationship between education and preparedness of health workers in dealing with DHF outbreaks in Banda Aceh City $(\mathrm{P}=0.148)$. The results of this study are different from the opinions expressed by Muttarak \& Pothisiri [23], namely that formal education has a positive relationship with the act of taking preparedness against disasters. Preparedness actions are influenced by various factors. Risk perception is strongly related to disaster preparedness because individuals must see risks to be motivated to initiate preparedness actions. Previous individual experiences with hazardous events can improve risk perception and promote preparedness actions. Other factors that influence 
preparedness behavior vary greatly with socio-economic and demographic characteristics. Individuals from different social groups receive and evaluate risk information differently and have unequal resources to carry out preparedness measures.

The results of this study are also different from the opinions expressed by Kasika [24], namely that education qualifications have a significant effect on work performance. The higher the level of education, the more the effect of education level and skills on job performance. Related to the preparedness of health workers for disasters, the higher the education of health workers, the higher their preparedness for disasters. The study put forward by Teddy [25] on factors related to the performance of health workers in the Seberang Padang Health Center Padang Selatan District, Padang City showed results that were in line with this study. The study conducted by [25] revealed that there was no significant relationship between the level of education and job training with the performance of health workers. Regarding the preparedness of health workers for disasters, the higher the education, the higher the preparedness of these health workers for facing disasters. Kotur \& Anbazhagan [26] studied the influence of education and work-experience-Influence to job performance and found that the performance shown by health personnel varies due to their educational qualifications. The general trend is that with increasing educational qualifications, the performance of health workers will decline. Based on the description above which is in line with this research, the researcher assumes that the education background of health workers in the sub-district public health center, Puskesmas, is not related to preparedness in dealing with DHF outbreaks in Banda Aceh City.

The results of the next study were that there was a significant relationship between the length of time served with the preparedness of health workers in dealing with DHF outbreaks in Banda Aceh City $(P=0,0001)$. The working period is related to the experience of health workers in dealing with disasters (DHF outbreaks). Hoffmann \& Muttarak [27] said that in addition to education, previous disaster experience is another key factor that determines disaster preparedness behavior. Health workers who have long worked at the sub-district public health center, Puskesmas, certainly have a lot of experience in dealing with DHF outbreaks so they have more preparedness than those who have just worked. Furthermore, Hoffmann \& Muttarak [27] said that someone who has faced a disaster in the past will learn about potential harmful impacts and consequently be better prepared for future disaster events. Theoretically, a person's experience of disasters previously can affect preparedness behavior through channels similar to education. Hazard awareness and risk perception, for example, are closely related to previous disaster experiences. Seeing or feeling the impact of a disaster can increase awareness about the potential for destruction, show the benefits of preparation and evacuation, and increase knowledge about how to recover afterward and how to overcome the threat of further disasters [27].

The working period of health workers in dealing with DHF outbreaks at the sub-district public health center, Puskesmas, will affect their preparedness for the outbreak of DHF. This is related to the experience of health workers in overcoming DHF outbreaks that have occurred in their working area in the past. Becker, Paton, Jhonston, Ronan, \& McClure [28] said that experience has seven different influences on the preparedness process including encouraging thinking and speaking; increasing awareness and knowledge; helping individuals understand the consequences of a disaster; developing trust; developing preparedness; affecting emotions and feelings; and encouraging someone's interaction about disaster issues.

Kiongo [29] also said that understanding the dimensions of disaster preparedness was found to be related to the work experience of health workers. This is consistent with research conducted in the Caribbean about the vulnerability of hospital staff to disasters which shows that there is a relationship between preparedness and work experience. A number of studies also 
show this relationship. Work experience in a risk environment leads to response predictions. Prediction is part of disaster mitigation. Mohammad-pajooh \& Aziz [30] argues that past experience can improve preparedness for disasters, because it affects someone to get more information about disasters and inform someone about the possibility of similar events in the future and as a result increases disaster preparedness. Seeing the effect of years of work through one's experience in facing disasters, the researchers argue that the length of duty or work period will affect the preparedness of health workers in the sub-district public health center, Pukesmas, in dealing with dengue outbreaks depends on experience and motivation at work.

The results of other studies are that there is a relationship between training and preparedness of health workers in dealing with DHF outbreaks in the city of Banda Aceh $(\mathrm{P}=0.028)$. The results of this study are in line with the research conducted by Hely [31], about the influence of knowledge and training on earthquake disaster preparedness training on the preparedness of health workers. The study shows that knowledge and training have a relationship and influence on earthquake disaster preparedness. However, this research is in line with the research conducted by Husna [11] on factors associated with the preparedness of health center workers in the face of earthquake and tsunami disasters in the city of Padang. The study showed that there was no relationship between training and preparedness of health workers at thesub-district public health center, Puskesmas $(\mathrm{P}=0.375)$.

Cotanda, Martines, Maza, \& Cubells [32] found that disaster management training programs significantly increased knowledge about disaster preparedness. Health workers feel more prepared to face disasters after the training program $(15.5 \%$ vs $41.8 \%, \mathrm{P}<0.001)$. However, Karanci, Aksit, \& Dirik [33] said that disaster training participants had a higher perception of the threat of disasters than those who did not attend training. An important issue of disaster awareness training is motivating individuals to take appropriate action. Thus, the trainees have been involved in more significant preparedness behaviors.

Alim, Kawabata, \& Nakazawa [34] said that training proved to be effective in increasing disaster preparedness knowledge and abilities for health workers. Juanita, Suratmi, \& Maghfiroh[35] also said that basic disaster management training and simulation training were more effective in increasing disaster preparedness for health workers. The attitude of disaster preparedness to health workers can be influenced by their experience in facing and participating in disaster events or disaster simulations. Changes in the attitude of health workers can be mediated by simulation experiences that enable deep and meaningful learnings. Based on the description above, it can be assumed that the training on disaster for health workers in the subdistrict public health center, Puskesmas, contributed greatly to the preparedness of health workers in dealing with dengue outbreaks in Banda Aceh City.

The next results of this study showed that there was no relationship between endemicity status and the preparedness of health workers in dealing with DHF outbreaks in Banda Aceh City $(\mathrm{P}=0.838)$. The results of this study are different from the opinions expressed by Yanagisawa, Wada, Spengler, \& Sanchez-Pina [36] namely the preparation for the emergence of the threat of infection is very important given the nature of infectious DHF disease. The pragmatic approach that must be taken is to have a preparedness plan so that health workers together with the community know how to recognize the symptoms and how to respond. WHO [2] further said that the human resource capacity of health workers must exist to effectively implement DHF prevention and control programs. The development of skills, processes, and resources of health personnel is needed in the field of case identification, case management, diagnostics, supervision, vector control, risk communication, surge and outbreak management, and evaluation. 
WHO [1] states that emergency preparedness and contingency planning must be explicitly included in DHF monitoring and control policies. These policies must be reviewed regularly. Emergency preparedness and response are often ignored by health workers and policy makers. When the dynamics of DHF activity is known, the timing of response activities can be adjusted by health workers to maximize their effectiveness. In DHF endemic areas, activities that must be carried out by health workers can be grouped into activities that must be made continuously, activities that must be conducted during epidemics, and activities that must be carried out in the post-epidemic period. Different activities and approaches may be needed in areas where DHF occurs sporadically and in areas with DHF fever at risk of transmission.

Zaputri, Sakka, \& Paridah [37] shows that the results of the countermeasure program for DHF are considered quite good. In the evaluation of inputs it was considered good enough, but the availability of personnel was still lacking. Process evaluation is considered good because it is in accordance with the program plan, but it needs to be improved in the process of epidemiological investigation activities which still have a number of obstacles related to incomplete patient data resulting in officers being late in responding to case reports. Output evaluation is considered good because almost every activity has reached a predetermined and proven target with the number of DHF sufferers decreasing from the previous year. Based on the results of the discussion above, the researchers assumed that endemicity status did not improve the preparedness of health workers in the sub-district public health center, Puskesmas, in the face of DHF outbreaks in Banda Aceh City. There are contributions from other technical factors such as the availability of trained health personnel and adequate facilities and infrastructure.

The results of the logistic regression analysis showed that age $(\mathrm{P}=0,0001)$, duration of duty $(\mathrm{P}=0,0001)$ and training $(\mathrm{P}=0,0001)$ were the most significant predictors of preparedness of health workers in the sub-district public health center, Puskesmas, in dealing with DHF outbreaks. The training was the most dominant predictor affecting the preparedness of health workers in dealing with DHF outbreaks (OR: 4,954) after being controlled by age (OR: 2,610) and length of time (OR: 0,145). The results of this study are just in line with those proposed by Kiongo [29], namely there is a significant relationship between age, disaster management training, experience and level of awareness with disaster preparedness on health workers. Mohammad-pajooh \& Aziz [30] also said in his research that the majority of social demographic indicators such as income, education, age, and property ownership showed a significant contribution to variations in disaster preparedness. For example, men are far more prepared than women; High levels of income and education also have a much higher readiness compared to those who have low income and education levels. The race is the only different factor from the findings of previous studies; because race does not affect preparedness.

Najafi et al.[15] said something different, namely the monthly income level, previous disaster experience, housing, and employment districts were demographic factors that significantly affected disaster preparedness. However, disaster preparedness is not influenced by gender, education level, number of household members, type of house, house ownership and being the head of the household. Other studies such as those conducted by Wahidah [13] found that there is a relationship between age, length of work, previous disaster experience, experience in refugee camps, self-regulation, health service atmosphere $(p<\alpha=0.05)$. From the multivariate analysis, it is known that the length of the work factor is the one that most influences nurse preparedness $(p=0.020)$. These results indicate that the duration of work affects nurse preparedness.

Chan, Yue, Lee, \& Wang [38] showed that middle-aged (40-64 years) and higher education are related to disaster preparedness. In addition, higher education, high income, and experience 
in work affect disaster preparedness. In addition, the older age group (40-64 years) has a higher preparedness compared to the young age group (15-39 years). Cvetković et al [21] said that demographic factors that are considered to have the most influence on disaster preparedness. Disaster preparedness varies depending on factors such as the type of disaster, location and time. The risk of death can vary by age and sex in different ways in each disaster. Demographic characteristics of the health worker are clear indicators of community risk perceptions. Disaster preparedness correlates with certain socio-demographic variables such as income, gender, education and age of the individual.

\section{Conclusion}

The preparedness of health workers in the sub-district public health center, Puskesmas, in dealing with DHF outbreaks in the city of Banda Aceh was strongly influenced by individual characteristics such as age, gender, position, length of duty and training. The older the age of health workers in the sub-district public health center, Puskesmas, the more ready they will be in dealing with DHF outbreaks in Banda Aceh City. The longer the health staff is on duty, the more ready they will be in dealing with dengue outbreaks in Banda Aceh City. Disaster and emergency training are very important for the preparedness of health workers in dealing with DHF outbreaks. The more often health workers attend training, the more prepared they are to deal with dengue outbreaks in Banda Aceh City.

\section{Acknowledgments}

Thank you to the respondents who participated in this study

\section{REFERENCES}

[1] World Health Organization, "Emergency risk management for health-overview," World Health Organization, 2013.

[2] World Health Organization, "Western facifik regional action plan for dengue prevention and control," WHO Western Pacifik Region, 2016.

[3] Dinas Kesehatan Provinsi Aceh, Profil kesehatan provinsi aceh 2015. 2016.

[4] Dinas Kesehatan Kota Banda Aceh, "Profil kesehatan kota banda aceh tahun 2014," Banda Aceh, 2015.

[5] Presiden Republik Indonesia, Peraturan Menteri Kesehatan Republik Indonesia Nomor 82 Tahun 2014. Republik Indonesia, 2014.

[6] UNISDR, Words into action guidelines; national disaster risk assessment, S. Safaie. 2017.

[7] Afif, "Kasus demam berdarah di banda aceh masuk kejadian luar biasa," Merdeka.com, 2017. .

[8] Dinas Kesehatan Kota Banda Aceh, "Profil kesehatan kota banda aceh 2017," 2018.

[9] C. Ogedegbe, T. Nyirenda, G. DelMoro, E. Yamin, and J. Feldman, "Health care workers and disaster preparedness: Barriers to and facilitators of willingness to respond," Int. J. Emerg. Med., vol. 5, no. 1, pp. 1-9, 2012.

[10] S. C. Desai, P. Doke, and N. C. Mohanty, "Role of health care workers during emergency preparedness in selected hospitals of navi mumbai," Int. J. Sci. Study, vol. 5, no. 3, pp. 77-80, 2017.

[11] T. M. Husna, "Faktor-faktor yang berhubungan dengan kesiapsiagaan tenaga 
puskesmas dalam menghadapi bencana gempa dan tsunami di kota padang tahun 2017," Universitas Andalas, 2017.

[12] LIPI-UNESCO/ISDR, "Community preparedness study in anticipating earthquake \& tsunami disasters," Jakarta, 2006.

[13] D. A. Wahidah, "Faktor-faktor yang mempengaruhi kesiapsiagaan perawat dalam menghadapi banjir di kecamatan gumukmas kabupaten jember," Univeritas Jember, 2016.

[14] V. J. Cornell, L. Cusack, and P. Arbon, "Older people and disaster preparedness: A literature review," Aust. J. Emerg. Manag., vol. 27, no. 3, pp. 49-53, 2012.

[15] M. Najafi, A. Ardalan, A. Akbarisari, A. A. H. Noorbala, and Jabbari, "Demographic determinants of disaster preparedness behaviors amongst tehran inhabitants, Iran," PLoS Curr., 2015.

[16] S. P. Robbins and M. Coulter, Management. India: Pearson, 2017.

[17] P. Drucker, The practice of management. Routledge, 2012.

[18] R. Bolden, Leadership, management and organizational development. 2010.

[19] R. Sharma, P. Webster, and S. Bhattacharyya, "Factors affecting the performance of community health workers in India: a multi-stakeholder perspective," Glob. Heal. Action, vol. 7, 2014.

[20] M. Mehta, "Gender matters: Lessons for disaster risk reduction in south asia," Int. Cent. Integr. Mt. Dev. (ICIMOD)., 2017.

[21] V. M. Cvetković, G. Roder, A. Öcal, P. Tarolli, and S. Dragićević, "The role of gender in preparedness and response behaviors towards flood risk in Serbia," Int. J. Environ. Res. Public Health, vol. 15, no. 12, 2018.

[22] M. A. Ashraf and M. A. K. Azad, "Gender issue in disaster: Understanding the relationship of vulnerability, preparedness and capacity," Environ. Ecol. Res., vol. 3, no. 5, pp. 136-142, 2016.

[23] R. Muttarak and W. Pothisiri, "The role of education on disaster preparedness: Case study of 2012 indian ocean earthquakes on thailand's andaman oast," Ecol. Soc., vol. 18, no. 4, 2013.

[24] B. D. Kasika, "The effect of educational qualification on job performance: the case of social security commission in namibia (SSC)," University of Namibia, 2015.

[25] W. Teddy, "Faktor-faktor yang berhubungan dengan kinerja petugas kesehatan di puskesmas seberang padang kecamatan padang selatan kota padang," Universitas Andalas, 2017.

[26] R. B. Kotur and S. Anbazhagan, "Education and work-experience - influence on the performance,” IOSR J. Bus. Manag., vol. 16, no. 5, pp. 104-110, 2014.

[27] R. Hoffmann and R. Muttarak, "Learn from the past, prepare for the future: Impacts of education and experience on disaster preparedness in the Philippines and Thailand," World Dev., vol. 96, pp. 32-51, 2017.

[28] J. S. Becker, D. Paton, D. M. Jhonston, K. R. Ronan, and J. McClure, "The role of prior experience in informing and motivating earthquake preparedness," Int. J. Disaster Risk Reduct., vol. 22, pp. 179-193, 2017.

[29] J. G. Kiongo, "Disaster preparedness among members of staff at kenyatta national hospital, nairobi county, Kenya.," Kenyatta University, 2015.

[30] E. Mohammad-pajooh and K. A. Aziz, "Investigating factors for disaster preparedness among residents of Kuala Lumpur," Nat. Hazards Earth Syst. Sci. Discuss., vol. 2, no. 5, pp. 3683-3709, 2014.

[31] Hely, "Pengaruh pengetahuan dan pelatihan kesiapsiagaan penanggulangan bencana 
gempa bumi kesiapsiagaan tenaga kesehatan terhadap di rumah sakit umum bunda thamrin kota medan Tahun 2013," University of Sumatera Utara, 2014.

[32] C. P. Cotanda, M. R. Martines, V. T. S. de la Maza, and C. L. Cubells, "Impacto de un programa de formación de catástrofes en el personal sanitario," An. Pediatr., 2015.

[33] A. N. Karanci, B. Aksit, and G. Dirik, "Impact of a community disaster awareness training program in Turkey: Does it influence hazard-related cognitions and preparedness behaviors," Soc. Behav. Personal. an Int. J., vol. 33, no. 3, pp. 243-258, 2015.

[34] S. Alim, M. Kawabata, and M. Nakazawa, "Evaluation of disaster preparedness training and disaster drill for nursing students," Nurse Educ. Today, vol. 35, no. 1, pp. 25-31, 2015.

[35] F. Juanita, S. Suratmi, and I. L. Maghfiroh, "The effectiveness of basic training on disaster management pilot program for disaster preparedness in community," Indones. Nurs. J. Educ. Clin., vol. 2, no. 2, pp. 126-135, 2018.

[36] N. Yanagisawa, K. Wada, J. D. Spengler, and R. Sanchez-Pina, "Health preparedness plan for dengue detection during the 2020 summer olympic and Paralympic games in Tokyo," PLoS Negl. Trop. Dis., vol. 12, no. 9, pp. 1-14, 2018.

[37] R. Zaputri, A. Sakka, and Paridah, "Evaluasi program penanggulangan penyakit demam berdarah dengue (DBD) di Puskesmas Puuwatu Kota Kendari tahun 2016," Jimkesmas, vol. 2, no. 6, pp. 1-14, 2017.

[38] E. Y. Chan, J. Yue, P. Lee, and S. S. Wang, "Socio-demographic predictors for urban community disaster health risk perception and hHousehold based preparedness in a chinese urban city," PLOS Curr. Disaster, 2016. 